ELORE (ISSN 1456-3010), vol. $18-2 / 2011$.

Julkaisija: Suomen Kansantietouden Tutkijain Seura ry.

[http://www.elore.fi/arkisto/2_11/mckeough.pdf]

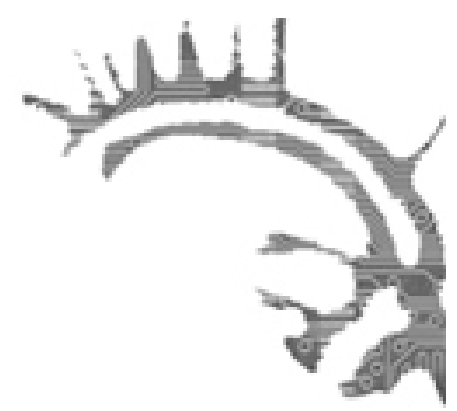

\title{
KIRJA-ARVIO
}

\section{SISÄLLISSODAN RAAMATULLISTEN TULKINTOJEN JÄLJILLÄ}

HUTTUNEN, NIKO 2010: Raamatullinen sota. Raamatun käyttö ja vaikutus vuoden 1918 sisällissodan tulkinnoissa. Helsinki: SKS. 301 sivua.

\section{Andreas McKeough}

Teologi Niko Huttusen tutkimus Raamatullinen sota. Raamatun käyttö ja vaikutus vuoden 1918 sisällissodan tulkinnoissa käsittelee nimensä mukaisesti sitä, miten Raamattuun on viitattu erilaisissa vuoden 1918 sotaa kuvaavissa ja tulkitsevissa teksteissä sekä ennen kaikkea sitä, minkälaisia ideologisia vaikuttimia nämä viittaukset heijastavat. Huttusen tutkimus on eksegetiikan alalta. Keskeiset tutkimusmetodit ovat intertekstuaalinen sekä reseptio- ja vaikutushistoriallinen analyysi. Huttunen paikantaa ensin aineistostaan intertekstuaalisella analyysilla ne tekstiosat, joissa esiintyy raamattukytkentöjä eli Raamatun reseptiota. Tämän jälkeen hän soveltaa reseptio- ja vaikutushistoriallista analyysia näihin tekstinosiin. Tällöin tarkasteltavana on se, sisältävätkö nämä Raamattuun viittavat tekstiosiot kirjoittajan antamia ideologisia merkityksiä, ja mikäli sisältävät, niin minkälaisia. Taustoittakseen analyysiaan Huttunen esittelee vuosisadan alun uskonnollista ilmapiiriä ja sen yhteiskunnallisia kytköksiä. Huttunen aloittaa tutkimuksensa punalesken kysymyksestä Taipalsaaren kirkkoherralle Aarni Voipiolle. Pastori ei osaa vastata lesken kysymykseen "sanokaa pastori, miksi he ampuivat mieheni?” vielä vuosikymmenienkään päästä, jolloin hän kirjoittaa muistelmissaan kysymykseen liittyen: 'Käypä sitä selittämään!' Huttunen myös palaa tähän samaiseen kysymykseen ja siihen vastaamisen vaikeuden pohdintaan teoksensa lopussa, mikä antaa sille mukavalla tavalla temaattisen sulkeuman tuntua. 


\section{SODAN PYHÄ LUONNE}

Huttunen on jäsentänyt tutkimuksensa johdannon ja loppupäätelmien ohella neljään temaattiseen lukuun. Ensimmäisessä näistä tarkastellaan Raamatun roolia osana apokalyptista historiavisiota, jota hahmotteli näkyvimmin Savonlinnan piispa Otto Immanuel Colliander. Huttunen esittelee Collianderin teologis-historiallista näkemystä, jossa sisällissota näyttäytyy osana Jumalan ohjaamaa maailmankulkua kohti apokalypsia. Colliander näki sisällissodan merkkinä sellaisen ajan saapumisesta, jota hän kutsuu kristokratiaksi. Tämän ajanjakson aikana maailmaa valmistetaan Jeesuksen paluuta varten ja ajalle on tyypillistä kristinuskon vihollisten kukistaminen. Collianderin sangen fundamentalistiselle ajattelulle oli leimallista myös demokratian - ilmestyskirjan petoon vertautuvan mielettömyyden - vastustaminen.

Collianderin näkemysten rinnalla Huttunen tarkastelee myös taiteilijoiden esittämiä apokalyptisia viittauksia vuoden 1918 sotaa kuvaavissa töissä. Laajimmin Huttunen käsittelee kahden ajalle merkittävän runoilijan, Bertel Gripenbergin ja Edith Södergranin, runoudessa esiintyvää apokalyptista tematiikkaa. Södegranin runoista välittyy ajatusmalli sisällissodan, ja valkoisen Suomenkin, luonteesta vain alkunäytöksenä uudelle ajalle, jolloin harvinaislaatuiset ja muita kyvykkäämmät yksilöt nousevat valtaan. Runojen apokalyptisen tematiikan ohella Gripenberg suhtautui myös avoimen hyökkäävästi niin sanottua sovintopolitiikkaa vastaan. Tämän politiikan tunnetuin kannattaja oli vastaitsenäistyneen tasavallan ensimmäinen presidentti K. J. Ståhlberg. Merkillepantavaa on, että Huttunen ei etsi ja analysoi tässä luvussa ainoastaan valkoisten tulkintoihin ja taiteeseen sisältyvää apokalyptista tematiikkaa vaan paikallistaa eskatologisia sävyjä myös punaisille tärkeissä teksteissä. Esimerkkeinä Huttunen nostaa esiin Punakaartin marssin tekstin ja punaista sotanäkökulmaa ymmärtämään pyrkivien ajattelijoiden, kuten kansanedustaja Matti Paasivuoren ja Axel Åhlstsrömin, sotaa käsittelevät kirjoitukset.

Sisällisodan tulkintojen apokalyptisten piirteiden jälkeen Huttunen siirtyy tarkastelemaan Paavalin esivaltaopetuksen asemaa sotatulkinnoissa. Ajatus Jumalan asettamasta esivallasta ja sen kautta hyväksyttävästä vallitsevasta yhteiskuntajärjestyksestä välittyy Raamatun ohella katekismuksesta, jota 1900-luvun alun Suomessa vielä luettiin ahkerasti ja laajalti. Sortovuodet vaikuttivat esivalta-ajattelun asemaan, mutta eivät poistaneet sen merkitystä. Valkoisella puolella ajateltiin, että punaiset ovat nousseet laillista yhteiskuntajärjestystä sekä jumalallista esivaltaa vastaan. Huttunen tarkastelee mielenkiintoisella tavalla sitä, miten niin punaiset kuin valkoisetkin toimitsijat kokivat punaisten kapinan nousemisena esivaltaa vastaan. Tilanne ei kuitenkaan ollut näin yksiselitteinen, sillä vuoden 1918 sota järkytti myös valkoisten käsitystä vallitsevan yhteiskuntajärjestyksen asemasta ennen kaikkea siksi, että se romutti ideaalin yhtenäisestä kansakunnasta.

Kolmantena kokoavana teemana sisällissotatulkintojen Raamattu-tulkinnoissa Huttunen nostaa esiin niin sanotun talioperiaatteen, lex talionisin. Se on Hammurabin laistakin - "jos joku puhkaisee vapaan miehen silmän, niin puhkaistakoon hänen silmänsä" - tuttu oikeudellinen periaate, joka Raamatussa tunnetaan Mooseksen lakina. Ajattelutavan periaate kiteytyy myös kuuluisaan lauselmaan ”joka miekkaan tarttuu, 
se miekkaan hukkuu". Huttunen esittelee muun muassa sitä, miten tätä periaatetta on sovellettu kuvaamaan ja perustelemaan Varkauden teloituksia valkoisten Suomen vapaussota kwissa-teoksessa, sekä sitä miten talio-periaate esiintyy sekä valkoisessa että punaisessa kaunokirjallisuudessa. Tämän lisäksi esitellään sisällisodan tulkintoihin sisältyviä viittauksia Abelin ja Kainin kohtaloon, joka on tunnetuin talio-periaatetta kuvaava kertomus. Näitä viittauksia sisältyy esimerkiksi Mannerheimin käskyihin ja niin valkoisiin kuin punaisiinkin kaunokirjallisiin teoksiin. Tämä ei ole yllättävää, sillä sodasta puhuttiin jo sen aikana veljessotana, vaikkakin saman perheen vesojen taistelu sodan eri puolilla todellisuudessa oli äärimmäisen harvinaista.

Viimeiseksi Huttunen tarkastelee sodan tulkintoihin sisältyviä, raamatullisen sisällön varassa konstruoituja uhri- ja syyllisyysideaaleja. Tässä luvussa Huttunen esittelee myös lyhyesti sisällissodan kauhutarinoita, joita Ulla-Maija Peltonen on tarkastellut laajasti punaisten kertomusperinnettä tarkastelevassa tutkimuksessaan Punakapinan muistot (1996). Huttunen ei juurikaan ammenna Peltosen teema-analyyttisesta kauhutarinatutkimuksesta vaan tyytyy ymmärrettävästi vain tarkastelemaan tiettyjen kauhutarinoiden raamatullisia aspekteja. Laajemmin Huttunen tarttuu punaisten ja valkoisten sodanjälkeiseen sankariuhrikuvaan, sen eroihin ja yhtäläisyyksiin. On mielenkiintoista, että Huttunen löytää sankariuhrin kolme keskeistä määritettä, uhrin vapaaehtoisuuden, tarkoituksellisuuden ja velvoitteellisuuden, molempien sotaosapuolten sankariuhrikonstruktioista ja niiden idealistisesta sisällöstä.

\section{MONISYINEN SOTA, MONINAISET TULKINNAT}

Niko Huttusen tutkimus on kompakti mutta systemaattinen ja taiten laadittu katsaus siihen, miten Raamattua ja sen tematiikkaa on sovellettu osana sisällissotatulkintoja. Se on paikkansa lunastava lisä vuoden 1918 tutkimukselliseen kenttään, joka näyttäisi olevan laajenemassa hyvää vauhtia siltäkin laidaltaan, jossa pääpaino annetaan historiallisten faktojen sijasta aikalaisten kokemuksille ja niiden tulkinnoille. Tutkimus ei ole teoreettisesti kunnianhimoinen, vaan hyvin empiirisesti painottunut. Kulttuurintutkimuksellisesta näkökulmasta on valitettavaa, että Huttunen ei kummemmin perustele aineistonsa muodostamista tai avaa lukijalle siihen liittyviä prosesseja. Tästä huolimatta Huttunen muodostaa monipuolisen aineistonsa analyysilla, jos ei holistisen niin ainakin hyvin laajan kuvan siitä, miten sodan jälkeen sotaan liittyviä näkemyksiä selitettiin ja perusteltiin yleisesti Raamattuun sekä sen teemoihin viitaten. Tämän ohella tutkimuksessa muodostuu elävä kuva 1900-luvun alkupuolen uskonnollisesta asenneilmapiiristä ja sen poliittisista kytkennöistä. Raamatun käyttö korostuu valkoisten sotatulkinnoissa, mutta Huttunen pyrkii tarkastelemaan ilmiötä laajasti myös punaisissa teksteissä. Punaisten ja valkoisten erilaiset tavat käyttää Raamattua sodan tulkitsemiseen heijastavat myös osaltaan punaisten ja valkoisten maailmankatsomuksellisia eroavaisuuksia sekä sotaosapuolten äärilaitojen välistä syvää aatteellista kuilua.

Huttusen tutkimus on suositeltavaa lukemista kenelle hyvänsä sisällissodasta kiinnostuneelle, mutta myös yleisemmin kotimaan historiasta ja erityisesti sen dramaattisista murroskausista kiinnostuneille. Tutkimuksessa nimittäin avautuu näköala myös 
järkyttävän sodan niihin piirteisiin, jotka tuntuvat nyt, miltei sadan vuoden päästä katseltuina, kovin vierailta tuntemallemme yhteiskunnalle: sodan julmuuteen ja molempien osapuolten ääriainesten aggressiiviseen ehdottomuuteen. Tutkimusote on historiallisesti painottunut halki tutkimuksen, joskin tutkijan teologinen osaaminen paistaa taustalla. Tämän lisäksi kirjan loppupäätelmissä ote on teologisempi Huttusen pohtiessa lyhyesti sitä, voiko tutkija tarkastella Raamattuun viittaavien tulkintojen "oikeaoppisuutta" ja sitä, miten sisällissota kuuluisi tulkita Raamatun valossa "oikein". Tutkija jättää tämän kysymyksen viisaasti auki lisäten, että siihen voi ylipäätään vastata vain valikoiden, muokaten ja tietynlaisesta tulkintakontekstista käsin. Näin tutkimuksen lopussa pallo siirtyy lukijalle, jolla on lukukokemuksen jälkeen kuva raamatullisten sotatulkintojen kirjosta ja siten mahdollisuus tehdä oma arvio niiden oikeudellisuudesta ja oikeaoppisuudesta henkilökohtaisesta tulkintakontekstista käsin.

\section{KiRJALlisuUS}

PELTONEN, ULLA-MAIJA 1996: Punakapinan muistot. Tutkimus työväen muistelukerronnan muotoutumisesta vuoden 1918 jälkeen. Helsinki: SKS.

Filosofian maisteri Andreas McKeough on folkloristiikan jatko-opiskelija Helsingin yliopistossa ja Suomen Akatemian rahoittaman Kansallista menneisyyttä rakentamassa -tutkimushankkeen jäsen. 